\title{
IMÁGENES SINIESTRAS: \\ EL DOLOR DE LOS DEMÁS (2018) \\ DE MIGUEL ÁNGEL HERNÁNDEZ
}

\author{
Antonio Candeloro \\ Universidad Católica San Antonio de Murcia (UCAM)
}

\section{RESUMEN}

El objetivo de este artículo es analizar de qué forma las imágenes presentes en El dolor de los demás, de Miguel Ángel Hernández, permiten desarrollar un discurso tanto narrativizado como teórico sobre lo siniestro, entendiendo el término en el sentido freudiano. Todas las fotos, los recortes de periódicos, las imágenes de obras artísticas contemporáneas presentes en la novela se irán convirtiendo a lo largo de la misma en epítomes emblemáticos a partir de los cuales el narrador protagonista reflexionará sobre la percepción del tiempo en relación con un pasado perturbador y sobre el bucle interpretativo (o el cortocircuito de las interpretaciones) en el que acaba sumergiéndose el que contempla esos mismos documentos visuales, sobre todo cuando una porción del pasado personal se configura como herida sangrante y trauma insanable.

Palabras clave: Miguel Ángel Hernández, El dolor de los demás, teoría de la literatura, imágenes y palabras, fotografía.

\author{
UNCANNY IMAGES: \\ EL DOLOR DE LOS DEMÁS (2018) \\ BY MIGUEL ÁNGEL HERNÁNDEZ
}

\section{Abstract}

The objective of this article is to analyze how the images which appear in El dolor de los demás, by Miguel Ángel Hernández, allow us to develop both a narrative and a theoretical discourse on the sinister, understanding the term in the Freudian sense. All the photos, the newspaper clippings, the images of contemporary artistic works present in the novel will gradually become emblematic epitomes from which the protagonist narrator will reflect on the perception of time in relation to a disturbing past. The narrator will also discover the risks of the interpretive loop (or the conflict of the interpretations) in which the one who contemplates those same visual documents ends up immersing himself, especially when a portion of the personal past is configured as a bleeding wound and unhealthy trauma.

Keywords: Miguel Ángel Hernández, El dolor de los demás, literary theory, images and words, photography. 


\section{INTRODUCCIÓN}

Publicada en el 2018, El dolor de los demás es la tercera novela de Miguel Ángel Hernández y se puede configurar como la tercera parte de una trilogía que incluye Intento de escapada (2013) y El instante de peligro (2015). Las tres obras giran alrededor de uno de los nudos más interesantes y sugerentes de la novelística contemporánea: las relaciones (siempre ambiguas y problemáticas) entre palabras e imágenes y, paralelamente, el conflicto de las interpretaciones que estalla en el mismo momento en el que el autor decide incorporar dentro del texto narrativo documentos visuales que, según los casos, amplían, contradicen o ponen en tela de juicio lo que se narra en el plano de la ficción ${ }^{1}$.

El objetivo de este artículo es analizar de qué forma las imágenes presentes en El dolor de los demás permiten desarrollar un discurso tanto narrativizado como teórico sobre lo siniestro, entendiendo el término en el sentido freudiano ${ }^{2}$. Todas las fotos, los recortes de periódicos, las imágenes de obras artísticas contemporáneas presentes en la novela se irán convirtiendo a lo largo de la misma en epítomes emblemáticos a partir de los cuales el narrador protagonista reflexionará sobre el pasado, sobre la percepción del tiempo en relación con un pasado perturbador y sobre el bucle interpretativo (o el cortocircuito de las interpretaciones) en el que acaba sumergiéndose el que contempla esos mismos documentos visuales, sobre todo cuando una porción del pasado personal se configura como herida sangrante y trauma insanable.

${ }^{1}$ En el caso que nos interesa la cuestión se complica ulteriormente, teniendo en cuenta que El dolor de los demás se basa en hechos reales y le ofrece al lector imágenes reales (sacadas de periódicos, telediarios, ensayos y muestras de arte contemporáneo). En este sentido, resulta fundamental la lectura de Aqui y ahora, el diario (o "work in progress») que Hernández lleva a cabo de forma paralela a la redacción de la novela (Hernández 2019a): en otro lugar analizaré detenidamente los cortocircuitos hermenéuticos a los que da lugar el análisis comparado de El dolor de los demás en relación con Aqui y ahora. Sobre los diarios del autor $c f r$. Alberca 2020a. Sobre el nudo «imágenes y palabras", cfr. Candeloro 2008, 2018 y 2019; Pittarello 2014a, 2014b y 2020. Se centra en el lector en cuanto espectador de los objetos visuales en el género narrativo Mora 2012; el mismo autor lleva a cabo una exhaustiva panorámica sobre los nudos teóricos que implica el uso de las imágenes dentro de los textos literarios en Mora 2019; se centra en el cine en cuanto generador de imágenes en la narrativa (cinéfila) de Javier Marías López López 2019; afronta el análisis cinematográfico de la pintura de Goya (y el origen goyesco del cine moderno) Quiñonero 2020. El mismo Miguel Ángel Hernández estudia las relaciones entre la novela y el arte en Hernández 2019b.

${ }^{2}$ Cfr. Freud 1976: 215-251; resulta significativo que este famoso ensayo empiece con una referencia explícita del autor a la estética, entendida en cuanto "ciencia de lo bello", una definición clásica e historicista de la misma, y en cuanto «doctrina de las cualidades de nuestro sentir», una definición más amplía y más certera (y cercana a la definición que nos ofrece Kant en su Crítica del juicio): dentro del ámbito de la estética tiene cabida precisamente también lo que Freud define como "ominoso", esto es, lo que pertenece "al orden de lo terrorífico, de lo que excita angustia y horror" (Freud 1976: 219); en la página siguiente hallaremos la famosa definición: «lo ominoso es aquella variedad de lo terrorífico que se remonta a lo consabido de antiguo, a lo familiar desde hace largo tiempo». Sobre la estética en cuanto filosofía no-especialista y asistemática cfr. Garroni 1986. 
Así empieza El dolor de los demás: «Han entrado en la casa de la Rosario, dice tu padre desde la habitación de al lado, han matado a la Rosi y se han llevado al Nicolás» (Hernández 2018: 13) ${ }^{3}$. Se trata de una frase que llama inmediatamente la atención del lector, al involucrarlo en un doble delito (una tragedia familiar por partida doble) y que, a lo largo de la novela, se convertirá casi en un ritornello obsesivo, un mantra de tipo macabro a través del cual el narrador en primera persona de singular intentará llevar a cabo una personal búsqueda del tiempo pasado para poder explicar y explicarse qué ocurrió la Noche Buena de una Navidad de hace veinte años, cuando él tenía tan solo dieciocho años y cuando Nicolás, su mejor amigo de los tiempos de la infancia y adolescencia, mató efectivamente a su hermana Rosario para luego huir y tirarse por un barranco de las inmediaciones de su pueblo en plena huerta murciana ${ }^{4}$. La novela se desarrollaría, así, bajo la forma de una quest, de una pesquisa, a mitad de camino entre la confesión íntima y autobiográfica (de ahí también la importancia de los capítulos redactados en segunda persona de singular -el tú en el que el yo del autor se desdobla casi como para poder contemplar mejor los hechos y distanciarse de los mismos, o mantener de los mismos una adecuada distancia de seguridad-) y la novela policíaca (o detective story), en la que alguien tiene que investigar y aclarar la verdad, aunque ya desde las primeras líneas de la trama se sepa quién es el asesino (Nicolás) y quién la víctima (Rosi), además de cómo acaba la historia (el asesino se tira por un barranco tras haber matado a la víctima), a falta del motivo que desencadenará la tragedia (¿por qué Nicolás mató a su hermana? ¿Mantuvieron una relación incestuosa, como se rumorea en el pueblo, o fue solo un brote de locura improviso y letal, una forma de autodestrucción irracional e incontrolable?).

Por un lado, entonces, El dolor de los demás podría analizarse desde el punto de vista de la autoficción ${ }^{5}$, con todos los límites que implica adoptar esta definición en el momento en el que el autor narra los hechos personales y autobiográficos

3 Todas las demás citas se sacarán de esta edición, indicando solo el número de páginas entre paréntesis.

${ }^{4}$ El íncipit se convierte en este otro ritornello obsesivo en el primer capítulo (donde emerge de forma fragmentada y en cursivas): «Hace veinte años mi mejor amigo mató a su hermana y se tiró por un barranco» (18-21-22).

5 Cfr. Sánchez Zapatero 2019 y Alberca 2020b. Del mismo autor es de provecho la lectura de La máscara o la vida. De la autoficción a la antificción (Alberca 2017), donde se lleva a cabo un interesante análisis del panorama de la literatura espańola actual, además de la del siglo xx, a partir de la tan abusada etiqueta autoficción. Cuando se cita al Javier Cercas de Soldados de Salamina para compararlo con El dolor de los demás de Miguel Ángel Hernández tendríamos que matizar mucho: como intentaré explicar en otro lugar, esa novela de éxito aparecida en el 2001 imita y revitaliza la estructura de The Quest for Corvo. An Experiment in Biography (1934) de Alphonse James Alfred Symons (hay traducción española: Symons 2005), una biografía novelada sobre un personaje cuya vida fue más novelesca que las novelas que podrían inspirar sus hazañas (lo que, en parte, se puede aplicar a la vida y las obras de Rafael Sánchez Mazas, uno de los protagonistas de la novela de Cercas). 
adoptando la máscara del investigador privado o del Sherlock Holmes que estudia un delito que atañe su propia vida personal; por otro lado, en cambio, se podría estudiar la novela en cuanto Bildungsroman, como propone acertadamente José María Pozuelo Yvancos, en cuanto la pesquisa y el buceo en el pasado le permitirán al autor en cuanto narrador y protagonista de su propia (des)aventura aprender algo nuevo sobre su propia identidad, aunque sea ex contrario ${ }^{6}$. Y sin duda alguna, este es uno de los nudos centrales alrededor de los cuales la trama de la misma novela se irá desarrollando y modificando a lo largo de sus seis capítulos, adquiriendo en cada uno de ellos una estructura peculiar: si en los primeros tres (Veinte años, El mar de niebla y Los llantos del pasado) el autor va desentrañado los misterios que impiden ver claramente la verdad, en los últimos tres (Performance, El dolor de los demás y $L a$ zona de sombra) el mismo Miguel Ángel Hernández tendrá que recapacitar sobre la posibilidad de explicar el enigma de forma cabal y racional, y solo cuando vuelva a contemplar una foto de su infancia, podrá modificar su propio punto de vista y enfocar los hechos luctuosos desde el punto de vista de Rosi, esto es, de la víctima, de quien no tuvo voz ni protagonismo dentro de la misma trama simplemente porque el autor no la vio o no se dio cuenta de cuánta importancia iba a cobrar su presencia ausente en el entramado de la misma novela ${ }^{7}$.

Es el paratexto el lugar en el que es posible entender la naturaleza de Bildungsroman de El dolor de los demás: «La memoria es, dolorosamente, la única relación que podemos sostener con los muertos", pone en exergo Miguel Ángel Hernández, citando del ensayo Regarding the Pain of Others (2003) de Susan Sontag, traducido al español con el título Ante el dolor de los demás. Se trata de un texto en el que la

${ }^{6}$ Cfr. Pozuelo Yvancos 2019 (el título del artículo de Pozuelo Yvancos se inspira en el ensayo El punto ciego del mismo Javier Cercas, publicado en el 2016 para Random House Mondadori). El problema de la identidad y de la construcción de una identidad es esencial tanto en Intento de escapada como en El instante de peligro: en el primer caso asistimos a las dudas existenciales y a las cuitas morales de Marcos, un joven aprendiz de crítico e historiador del arte; en el segundo caso a la crisis existencial de Martín Torres, un profesor de Historia del Arte de cuarenta años. Ambos personajes son interpretables como máscaras del autor en cuanto comparten con él muchos rasgos biográficos.

${ }^{7}$ El hecho de que la obra se estructure según la bipartición tripartita citada no nos puede distraer ni hacer olvidarnos de que, por muy autobiográfica que sea, estamos ante una novela, esto es, una narración extensa que cuenta unos hechos según un determinado plan de significados; a pesar de que no haya ninguna teleología o ningún final aclaratorio ni catártico que permita esclarecerlo todo o que consienta explicar el enigma, pues el enigma sigue siendo tal incluso en la última página de la obra. La falta de un final certero y la renuncia a buscarlo se reafirma incluso en el ya citado diario del autor, Aqui y ahora: cfr. Hernández (2019a: 227-265), sobre todo, el "Epílogo», subtitulado significativamente «el sentido de un final» (alusión evidente al famoso ensayo de 1967 de Frank Kermode sobre cómo terminan las novelas $-\mathrm{y}$ sobre por qué tienen que terminar, antes o después-: The Sense of an Ending; cfr. Kermode 1983). En este sentido, resultarán fundamentales las reflexiones del mismo autor cuando afirme: «Eres consciente de que hay un momento en el que el diario y la novela van a coincidir. De hecho, juegan a reflejarse. Son reverberaciones. Quien lea esto, cuando llegue a la novela, recordará algo de lo escrito; tendrá una experiencia previa de aquello a lo que se va a enfrentar. $Y$, al revés, quien la lea la novela primero y, por curiosidad, se acerque entonces al diario, revivirá esos momentos de construcción» (Hernández 2019a: 79-80). 
escritora y crítica americana reflexiona sobre las imágenes violentas y sobre nuestra relación con las fotografías que dan testimonio del horror del que es capaz el ser humano: desde las fotos de Robert Capa en la guerra civil española hasta las de los campos de concentración nazi de la Segunda Guerra Mundial ${ }^{8}$, desde los mismos Caprichos y los Desastres de la guerra de Goya hasta las imágenes de los niños exterminados por los marines durante la guerra del Vietnam, Sontag vuelve sobre la importancia que tienen las fotografías para el conocimiento cabal y crítico del mundo que nos rodea, ampliando, en parte, los interrogantes que ponía sobre la mesa en On Photography, ensayo aparecido en $1973^{9}$, esto es, siete ańos antes de que Roland Barthes publicara su ya clásico estudio La chambre claire. Note sur la photographie (1980). Si comparamos el texto de Susan Sontag con el de Roland Barthes podremos ver claramente cómo ambos empiezan a reflexionar sobre la memoria en cuanto herramienta intelectual que el ser humano explota y puede expandir o, al revés, poner en entredicho precisamente gracias y a través del soporte de la imagen fotográfica. Esto es: reflexionar sobre la fotografía es también (implica inevitablemente) reflexionar sobre la memoria y sobre nuestra capacidad de retener el pasado que nos atañe o del que somos solo y simplemente testigos oculares ${ }^{10}$. Es lo que afirma Sontag en el fragmento evocado por Miguel Ángel Hernández en el paratexto de El dolor de los demás:

Quizá se le atribuye demasiado valor a la memoria y no el suficiente a la reflexión. Recordar es una acción ética, tiene un valor ético en y por sí mismo. La memoria es, dolorosamente, la única relación que podemos sostener con los muertos. Así, la creencia de que la memoria es una acción ética yace en lo más profundo de nuestra naturaleza humana: sabemos que moriremos, y nos afligimos por quienes en el curso natural de los acontecimientos mueren antes que nosotros: abuelos, padres, maestros y amigos mayores. La insensibilidad y la amnesia parecen ir juntas. Pero la historia ofrece señales contradictorias acerca del valor de la memoria en el curso mucho más largo de la historia colectiva. Y es que simplemente hay demasiada injusticia en el mundo. Y recordar demasiado (los agravios de antańo: serbios, irlandeses) nos amarga. Hacer la paz es olvidar. Para la reconciliación es necesario que la memoria sea defectuosa y limitada (Sontag 2019: 97-98) ${ }^{11}$.

${ }^{8}$ Sobre este tipo de imágenes es fundamental Didi-Huberman 2004; sobre una reflexión filosófica más amplia sobre la dificultad y, al mismo tiempo, la necesidad de dejar constancia del recuerdo de este tipo de horrores $c f r$. Agamben 1998 (hay traducción española: Agamben 2002).

${ }^{9}$ Cfr. S. Sontag 2018.

${ }_{10}$ Sobre este nudo $c f r$. Angelucci 2017 y Piazza 2014.

${ }^{11}$ La cita de Sontag recuerda otra de Juan Benet: «[...] a mí me parece que es el tiempo la única dimensión en que pueden hablarse y comunicarse los vivos y los muertos, la única que tienen en común» (Benet 1983: 49). El artículo apareció originalmente en la Revista de Occidente, V, 54, 1967, esto es, treinta y seis años antes de la reflexión de Sontag. Javier Marías citará esta misma reflexión de Benet en Negra espalda del tiempo (Marías 1998) para luego convertirla en un leitmotiv de todas sus novelas posteriores. 
He aquí un problema fundamental de quien decide emprender la búsqueda del tiempo perdido, sobre todo si este fragmento temporal atañe su propio pasado autobiográfico: la memoria es el único recurso, el instrumento básico imprescindible para poder mantener una relación con los muertos, a pesar de que se configura a menudo (y no solo en el ámbito de la ficción literaria) como una especie de diálogo silencioso de carácter ético (recordar es, en este sentido, hacer justicia a las víctimas), pero, al mismo tiempo, un arma de doble filo, porque recordarlo todo (o recordar demasiado) «nos amarga», nos lleva a recordar el dolor de los demás, lo que puede implicar o una falsa reconciliación o una imposibilidad real, objetiva, de reconciliarnos con el pasado (sobre todo, repito, si este pasado tiene que ver con nuestros familiares o amigos íntimos o allegados más cercanos).

Es precisamente lo que ocurre en un relato que Miguel Ángel Hernández publica en Cuaderno [...] duelo, una recopilación de cuatro textos aparecida en el 2011 (esto es, siete años antes de la publicación de El dolor de los demás). El primer relato (casi una novela corta: ocupa cincuenta y cuatro páginas) se titula precisamente Cuaderno duelo -sin los puntos suspensivos y entre corchetes-: en una especie de diario redactado de forma alterna entre la tercera y la segunda persona de singular, el narrador nos hará partícipes del luto y del dolor que sentirá al presenciar (al ser testigo ocular) de la muerte de su madre, fallecida en marzo del 2008. La tensión gramatical entre una y otra voz se hace casi desgarradora, además de inquietantemente palpable, en el momento en el que el narrador acude al tanatorio, donde, desgraciadamente, tomará conciencia de la irreversibilidad de los acontecimientos: su madre ha muerto, ya no está. Cito - para volver sobre otras escenas de este magnífico relato más adelante, en el curso de este análisis- el momento exacto en el que la tercera y la segunda persona de singular casi se solapan o se dan la mano la una a la otra (igual que en $E l$ dolor de los demás, también aquí la segunda persona aparece en cursivas):

$Y$ es aún el rostro que te miró, las manos que te acariciaron, el cuerpo que te acogió. Por un momento el cuerpo es todo eso. Pero ya nunca más la voz. Ya nunca más la mirada. Ya nunca más el tacto. Y aun sin mirada, sin tacto y sin voz, por un momento, el cuerpo sigue siendo una madre (Hernández 2011: 26).

Los cinco sentidos están casi todos evocados y alerta; y hay momentos en los que el narrador parece percibir al cadáver como un ser vivo («el cuerpo sigue siendo una madre»). Se trata de una fenomenología de la imagen (en este caso, de la imagen de alguien ya fallecido y expuesto - de forma incluso obscena precisamente porque espectacularizada- dentro de un tanatorio para el último y extremo saludo) que involucra al lector no tanto a un nivel intelectual y racional, sino sobre todo en el ámbito de las emociones (de lo patético, en cuanto fuente y generador o multiplicador de pathos). Pero si cito este relato es también porque vuelve a aparecer la misma Susan Sontag y en relación estrecha con lo que será (siete años después) el título de la novela que nos ocupa ahora: cansado de acudir al hospital para, esta vez, acompañar los últimos días de vida de su padre, ingresado en la UCI, y consciente de que empieza a encontrar un mínimo de desasosiego solo cuando se pone a comer en la cantina del hospital, el narrador imagina la trama para el siguiente potencial relato: 
Fue en ese momento, al verse como un voyeur del sufrimiento, cuando empezó a rondar por su mente el argumento para un relato que quizá escriba algún día: la historia de un hombre que, tras haberlo perdido todo, sólo pudo, en adelante, desayunar, comer y cenar en la cantina del hospital, reconfortándose, desde la distancia, con los momentos de sosiego del dolor de los demás (Hernández 2011: 44) ${ }^{12}$.

De nuevo, la reflexión sobre el pasado, en este caso, el pasado más íntimo y privado, se proyecta en el ámbito de la escritura y de la literatura, y se liga también a la fenomenología de las imágenes: no es casualidad que el narrador compare el rostro de su padre moribundo al de Thomas Bernhard, del que está leyendo en esos momentos El malogrado; y el solapamiento entre vida y literatura es tan explícito y perturbador que el narrador emprenderá otro tipo de análisis al acompañar a su padre en el nicho en el que colocarán su tumba, de forma paralela (e igual de escalofriante y emocionante) a la escena de la madre expuesta a la mirada ajena en el tanatorio:

Y todo acaba con una pared. El ataúd, encerrado tras un muro de ladrillos. Tiempo muerto, tiempo infructuoso. Es el momento más duro. Las lágrimas se hacen cemento. Y se paran. Nadie respira. Nada se escucha. Y, sin embargo, allí está el ruido más ensordecedor. El yeso y los ladrillos. La albañilería de la muerte (Hernández 2011: 57) ${ }^{13}$.

12 Las cursivas son mías. Chuck Palahniuk inventa otro «voyeur del sufrimiento» en Fight Club (su primera novela -aparecida en 1996-y de la que en 1999 David Fincher sacará su famosa versión cinematográfica homónima): el anónimo protagonista acudirá a los centros de enfermos terminales de cáncer para poder abrazar literalmente el dolor de los demás y, así, percibirse como alguien vivo (o que sigue con vida) a pesar de la depresión que lo llevará (casi) a la locura.

${ }^{13}$ En El dolor de los demás aparecerá una variante muy significativa de esta fenomenología de la muerte en una escena emblemática: volviendo a la casa de sus padres, el autor-narrador-protagonista volverá a toparse con las dos sillas en las que solían sentarse sus padres antes de su muerte: "Allí continuaban los dos sillones-mecedora, en torno a la mesa camilla, en el mismo espacio que invariablemente habían ocupado, como dos fantasmas, mirando hacia la ventana que se abría hacia el carril. Verlos dispuestos de esa manera me hizo contemplar directamente el pasado. Una escenografía sin personajes. El cuerpo de las cosas» (122). Si, por un lado, los dos sillones son metonimia de la ausencia de los padres, por otro, el hecho de que sigan ahí, en el mismo espacio doméstico, tras la tragedia de Nicolás y Rosi y el paso de los ańos, los convierte en dos fantasmas que siguen rondando por el mismo espacio familiar: podemos hablar en este caso de lo siniestro en cuanto "permanente retorno de lo igual» (un pasado que no pasa y que por eso produce pavor): $c f r$. Freud 1976: 234. Cuando, en cambio, el protagonista se acercará al cementerio y contemplará la tumba de Nicolás, llegará a otra reflexión sobre la representación gráfica de la muerte a partir de las fotos de las lápidas: «Pero las fotografías funerarias son siempre diferentes, aunque en el fondo provengan de un instante cualquiera, de un momento congelado. Pretenden condensar toda una vida, reunirla en torno a una representación, como el nombre y los apellidos, como la fecha de nacimiento y de muerte. Son los ojos del cadáver. La imagen última. La efigie definitiva» (291). De nuevo, la contemplación de una fotografía implica una reflexión sobre la percepción del tiempo, la función de la memoria y la imposibilidad de captar la identidad del muerto a través de la última imagen, la que los supervivientes eligen (a lo mejor sin su consentimiento previo) y le atribuyen como si fuera, efectivamente, la «efigie definitiva». 
El acto de mirar detenidamente todo el proceso que conlleva «enterrar a su propio padre»; la elaboración a través de la escritura (con un estilo casi beckettiano) de la fenomenología de la muerte a partir de lo que aquí se define de forma muy icónica y acertada como «la albañilería de la muerte», serán fundamentales también en El dolor de los demás, donde ese mismo tipo de análisis se emprenderá con respecto a las fotografías que pautan el texto. Y es el momento de ver cómo funcionan estas imágenes en relación con la búsqueda del tiempo perdido del autor, narrador y protagonista de El dolor de los demás.

\section{LAS IMÁGENES SINIESTRAS DE EL DOLOR DE LOS DEMÁS}

La primera imagen con la que el lector se topa en el curso de la lectura de la novela aparece en el cap. II, El mar de nieblas, un título nada casual y muy significativo, como veremos en seguida. Investigando entre los periódicos que hablaron o se ocuparon del caso, el autor consigue encontrar la portada del periódico local La Verdad: en la foto, se puede contemplar a dos figuras humanas en el borde del barranco desde el que se tiró Nicolás tras haber matado a Rosi. El pie de la foto es escueto y objetivo, pero también apto para llamar la atención morbosa del lector: «El barranco de 20 metros desde el que se arrojó el joven» (137). El hecho de que el cronista subraye la altura del barranco contribuye a percibir el horror de la escena vivida por quien, tras matar a su hermana, decide acabar también con su propia existencia. La pregunta que surge espontánea es jen qué pudo pensar el suicida a lo largo de esos veinte metros antes de estrellarse al suelo? En el autor, la visión de esta imagen provoca otro parecido efecto perturbador: «Me quedé un tiempo hipnotizado por la fotografía. Las dos figuras detenidas mirando fijamente al abismo [fig. 1] me recordaron los cuadros de Caspar David Friedrich» (137) ${ }^{14}$ :

Se trata de la lectura de un experto de arte, alguien que mira las imágenes desde el punto de vista de la historia del arte; pero, al mismo tiempo, se trata de una lectura plausible, porque, efectivamente, como aclara el autor:

Probablemente el redactor del periódico no lo pensó de modo consciente, pero lo cierto es que allí había una especie de llave para la interpretación del suceso: la tragedia, el crimen inimaginable, lo que no cabe en cabeza alguna. Como las figuras que miran desde el borde del barranco a la lejanía. Todos estaban paralizados, nadie entendía nada. Caminantes frente a un mar de niebla (138).

Esta posible «llave para la interpretación» remite, evidentemente, al cuadro más famoso del pintor romántico alemán: Der Wanderer über dem Nebelmeer, esto

${ }^{14}$ Cfr. Hernández 2019a: 23; 245-246, donde el autor nos narra y detalla otro tipo de reacción en el momento en el que consigue contemplar las casi cien fotos del periódico guardadas en el Archivo Regional de Murcia y donadas al mismo por la familia del autor, Tito Bernal. 


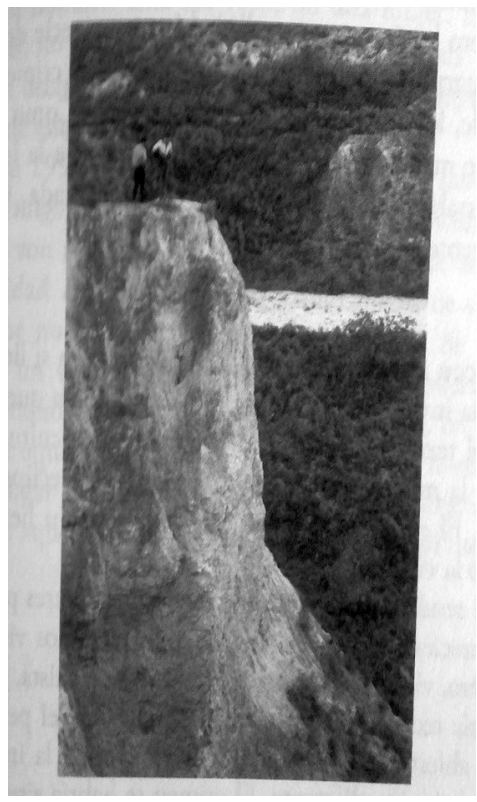

Fig. 1. «Barranco»: Fotografía aparecida en el periódico La Verdad, 26/12/1995. (C) Tito Bernal. Cortesía del Archivo Regional de Murcia.

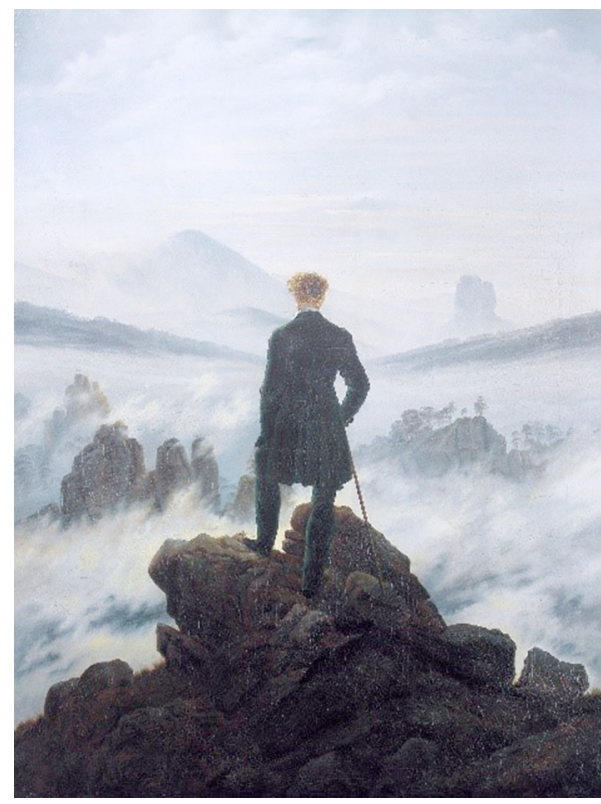

Fig. 2. Caspar David Friedrich, Der Wanderer über dem Nebelmeer (1818).

URL: https://historia-arte.com/obras/caminante-sobre-un-mar-de-nubes-de-friedrich.

es, El caminante sobre el mar de nubes, de 1818 (fig. 2). A pesar del doble deslizamiento léxico («frente», en lugar de «sobre», y «niebla», en lugar de «nubes»), el contenido tanto de la foto de La Verdad como del cuadro de Caspar David Friedrich es el mismo: la representación visual del hombre frente al abismo, esto es, del cuerpo de un ser humano increíblemente empequeñecido frente a la percepción de lo sublime de la naturaleza, entendiendo con este término lo que Kant define como «lo inmensamente grande», lo que la razón humana no puede calcular ni dominar ni abarcar ni tampoco llegar a imaginar de forma cabal y que, por ese mismo motivo, puede provocar y transmitirnos pánico o terror (Kant 1876: 76-90).

En realidad, si miramos detenidamente la obra pictórica, nos daremos cuenta de que hay varias diferencias entre el personaje del caminante que, apoyándose con un bastón en una roca de la cumbre de la montaña, contempla a lo mejor extasiado (y no solo amedrentado) el paisaje natural formado por las nubes que dificultan (o impiden) la visión de lo que hay más allá, y las dos figuras humanas de la fotografía del periódico: de las dos figuras, solo una nos enseña la espalda, igual que el caminante del pintor alemán; mientras que ambas manifiestan una postura de resignación o de impotencia, al posicionar las manos en la cadera, mientras miran el fondo del barranco, como para indicar con su postura física que llegan tarde y que, desgraciadamente, ya no hay nada que hacer. Si Friedrich nos oculta el resto del pai- 


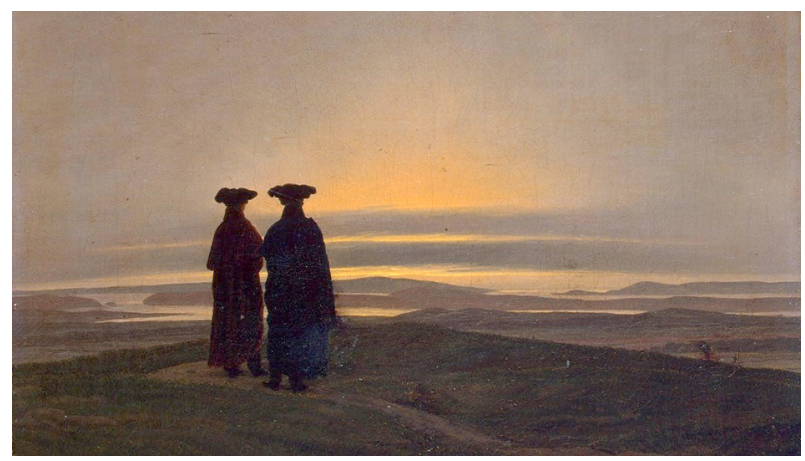

Fig. 3. Caspar David Friedrich, Sonnenuntergang (Brüder) oder Abendliche Landschaft mit zwei Männern (1830-35).

URL: https://commons.wikimedia.org/wiki/File:Abendlandschaft.JPG.

saje tapado por el mar de niebla, además del rostro del que contempla ese mismo paisaje, la foto del periodista de La Verdad nos oculta algo todavía más siniestro y escalofriante, esto es, el cadáver del asesino, que está ahí, en el fondo del barranco, aunque no lo veamos y aunque ese barranco, tal y como está encuadrado, parece no tener fondo. La misma medida exacta y matemática -veinte metros- no puede permitirnos entender la magnitud de la tragedia ${ }^{15}$. El cadáver se queda fuera del encuadre. Y si es verdad que, tal y como afirma Susan Sontag, "fotografiar es encuadrar, y encuadrar es excluir» (Sontag 2019: 45), entonces, el hecho mismo de que el periodista nos ahorre la visión del cuerpo que se ha tirado por el abismo (el hecho de que lo excluya de la visión) adquiere una importancia simbólica fundamental: encuadrar a los cadáveres puede resultar obsceno; y puede convertir la tragedia de la que se da noticia en algo todavía más morboso. Al mismo tiempo, es precisamente esa exclusión de la aparición del cuerpo del suicida lo que provoca que nos figuremos su presencia, o, al revés, su ausencia llamativa (su ausencia presente).

Hay otro cuadro de Friedrich en el que aparecen dos figuras humanas contemplando otro mar de niebla (fig. 3). Se titula Sonnenuntergang (Brüder) oder Abendliche Landschaft mit zwei Männern, esto es, Atardecer (Hermanos) o Paisaje al atardecer con dos hombres (de 1830-35).

Lo que nos llama la atención es que, esta vez, no hay abismo ni barranco desde el que contemplar el paisaje (y asustarse); el sol está a punto de desaparecer detrás de las nubes y de las montañas que se ven a lo lejos. Y los dos personajes son hermanos, como nos informa el título de la obra: ligados por la sangre, aquí apa-

15 Kant habla también de «sublime matemático» y nos recuerda que «toda determinación de la magnitud de los fenómenos no puede suministrar un concepto absoluto de la magnitud, sino solamente un concepto de comparación» (Kant 1876: 80). 
recen unidos también por la misma sorpresa (y éxtasis) que provoca el contemplar un atardecer juntos desde ese concreto punto geográfico y espacial. Si las dos figuras humanas de la foto del periódico llegan tarde, los dos hermanos de esta obra de Friedrich llegan puntuales, justo en el momento en el que pueden contemplar juntos el atardecer, esto es, el sol que esparce sus últimos rayos sobre las montańas y el paisaje en general, antes de desaparecer del todo.

Pero hay más: leyendo los varios recortes de los periódicos de la época, el autor, narrador y protagonista de la novela se da cuenta de que nadie habla de violencia de género o de violencia machista; esto lo empuja a reflexionar sobre los cambios terminológicos del lenguaje periodístico y sobre cómo, al cambiar la sintaxis y la semántica, además del léxico, se modifica también la manera de interpretar el mundo:

El lenguaje cambia, y con él, el tratamiento de la actualidad. Y también la producción y reproducción de la realidad. Las cosas son tal y como se dicen. El lenguaje es verdaderamente performativo; crea el mundo en que vivimos. Así que en 1995 no había violencia de género. Aquello había sido un crimen entre hermanos, un fratricidio. Un caso aislado. Él era Nicolás, un hombre. Ella era Rosi, no una mujer. Estaba sola ante él; no entraba en la triste lista de las demás. Se trataba de un hecho inexplicable, por eso nadie encontraba la manera de asumirlo $(139)^{16}$.

Si volvemos a contemplar la foto de los dos primeros testigos de la muerte de Nicolás en el lugar desde el que este se tira al vacío, nos daremos cuenta de que también las imágenes son "performativas» y de que "crean el mundo en que vivimos». El hecho de elegir encuadrar a los dos testigos oculares dentro del contexto sublime de una naturaleza que da vértigo y transmite terror también es una manera de encuadrar el mundo y de generar posibles interpretaciones de la tragedia familiar, como se percata y explica el autor. Y también es una forma de interpretar el comparar la fotografía con los cuadros de Friedrich, un pintor de la época romántica, esto es, de la primera mitad del siglo XIx. Entre ese determinado arco temporal y 1995, el que escribe (en el plano temporal de la actualidad, en el 2018) construye un puente metafórico a través del cual una imagen (de crónica local) dialoga con otra (del arte occidental más representativo del Romanticismo) dando lugar a un cortocircuito interpretativo muy productivo y eficaz tanto desde el punto de vista visual como narrativo. Frente al abismo (delante del barranco) el ser humano sigue manteniendo la misma postura dicotómica: de miedo, respeto y contemplación muda de la grandeza sublime de la naturaleza o, al revés, de pánico y terror, o, en los casos extremos, como el del asesino de Rosi, de deseo destructor y nihilista que empuja a caer hacia el fondo del abismo. El anacronismo de las imágenes siniestras

16 Más allá de la cuestión del género, Paul Ricoeur nos recuerda algo central (Ricoeur 2006: 26): «obrar mal es siempre dañar a otro directa o indirectamente y, por consiguiente, hacerlo sufrir; en su estructura relacional-dialógica-, el mal cometido por uno halla su réplica en el mal padecido por el otro». Está claro que -como ya explicó Aristóteles en su Poética- el efecto catártico de la tragedia aumenta cuando la violencia estalla entre padres e hijos, madres e hijos, o entre hermanos, como es el caso que nos atañe. 


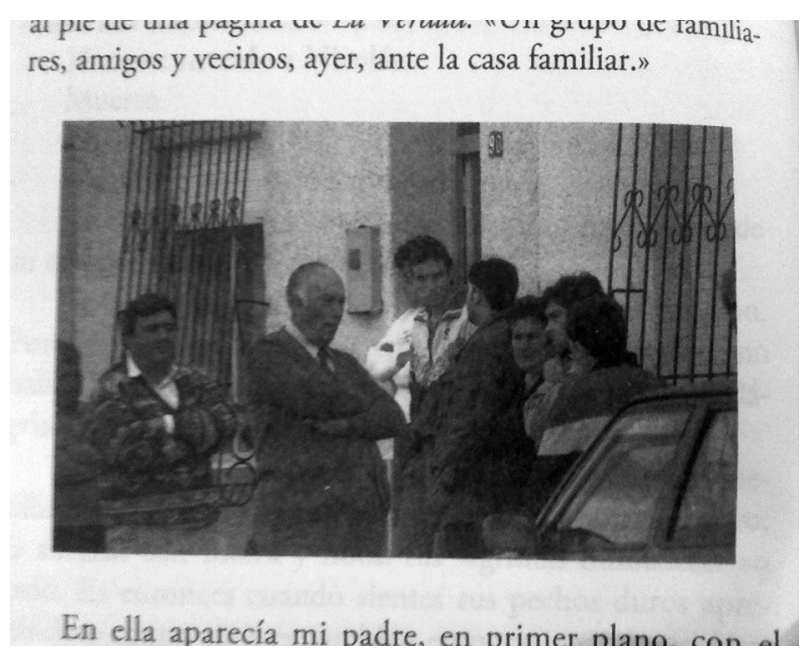

Fig. 4. "Grupo de personas».

Fotografía aparecida en el periódico La Verdad, 25/12/1995.

(C) Tito Bernal. Cortesía del Archivo Regional de Murcia.

involucradas en la narración rememorativa del autor permite llegar a concluir que, desde el punto de vista de la respuesta emotiva, no hemos cambiado mucho entre la época de Friedrich y nuestra contemporaneidad.

La segunda imagen que aparece en la novela es otra fotografía sacada de La Verdad: «Un grupo de familiares, amigos y vecinos, ayer, ante la casa familiar» (fig. 4) (142).

En la foto el autor reconoce inmediatamente a su padre «en primer plano, con el gesto serio y los brazos cruzados sobre su barriga prominente, en una pose muy suya que casi había olvidado y que me conmovió en cuanto la vi» (142). Y en seguida reconoce a los demás vecinos, casi todos en la misma postura del padre, con los brazos cruzados. Solo en un segundo momento, y gracias a un «chaquetón verde», el autor se reconoce a sí mismo, vuelve a ver a su yo adolescente, «con las manos en los bolsillos» (142) y hablando con Juan Alberto, primo de Nicolás. Desde el punto de vista kinésico, el tener las manos en los bolsillos o el mantener los brazos cruzados indican prácticamente lo mismo: la imposibilidad de entender y la espera (de que alguien explique de forma clara qué hay que hacer y qué acaba de pasar). La contemplación de la imagen prosigue:

Había algo siniestro en la fotografía. Podía reconocer prácticamente a todos los personajes de la imagen y, sin embargo, me resultaban extraños. La escena estaba filtrada por la oscuridad del crimen. La textura de la fotocopia o del escaneo de la imagen lo alejaba todo mucho más atrás en el tiempo. Parecía tomada en los años cuarenta. Una fotografía de El Caso. Una imagen propia de la Espańa profunda, ese país oscuro que habita nuestra consciencia colectiva y que se actualiza con cada nuevo crimen, con cada nuevo desastre (143). 
Es llamativo el hecho de que el autor utilice el término freudiano «siniestro» precisamente a partir de una foto tan familiar y tan aparentemente inocua. En su famoso ensayo titulado Lo ominoso (1919), Sigmund Freud define este concepto como algo que pertenece «al orden de lo terrorífico, de lo que excita angustia y horror» (Freud 1976: 219), para luego ampliar y especificar: «lo ominoso es aquella variedad de lo terrorífico que se remonta a lo consabido de antiguo, a lo familiar desde hace largo tiempo» (Freud 1976: 220). Si la familia es el lugar de lo familiar por antonomasia, el hecho de que cerca o al lado de la casa familiar se haya llevado a cabo un doble crimen empieza a conferir rasgos ominosos (o siniestros) a la imagen. El autor reconoce y, al mismo tiempo, percibe como «extraños» a los personajes que aparecen en la foto porque, debido al blanco y negro de la misma y, sobre todo, al aura de terror que el crimen parece expandir en su entorno familiar, lo precisamente familiar se convierte en su contrario, esto es, en lo no-familiar, lo que puede provocar terror o angustia. Los vecinos y su propia familia parecen aquí pertenecer a una foto sacada en los años cuarenta (esto es, en la época inicial del franquismo). Tanto es así que Miguel Ángel Hernández llega a pensar que esa imagen bien podría ser interpretada como una típica foto de El Caso, un famoso semanario de sucesos fundado en 1952 y especializado en contar los hechos de crónica más cruentos o sanguinarios. De nuevo, igual que en el caso de la primera foto, las imágenes se solapan y, al mismo tiempo, invitan al espectador a acercar de forma casi inmediata e inconsciente dos planos temporales alejados entre sí: es como si el fratricidio del mejor amigo del autor evocara el lado más oscuro de su propio país, aquel proverbial (y unamuniano) cainismo que llevó a la guerra civil y, consecuentemente, a los cuarenta ańos de dictadura franquista. Pero lo que llama la atención en el fragmento citado es que ese cainismo adquiere rasgos cíclicos: cada nuevo crimen, cada nueva tragedia familiar renueva y actualiza el lado oscuro de España (como si la historia fuera una retahíla de crímenes; o una pesadilla de la que nadie nunca pudiera despertar del todo).

El Romanticismo alemán evocado a partir de la primera foto de La Verdad hace rima con la guerra civil y el franquismo evocados a partir de la foto siniestra en la que aparecen el autor, junto con su padre y sus vecinos, vistos, ahora, en el presente de la escritura, como personajes sacados de El Caso, semanario dedicado a lo morboso y publicado durante todo el franquismo y hasta los años noventa.

La sombra de los fantasmas del pasado vuelve en el cap. III, Los llantos del pasado. A fuerza de escarbar en el delito de su mejor amigo, el autor empieza a sufrir insomnio y a tener pesadillas angustiosas. Una noche sueña con Nicolás o con Rosi o con ambos mientras intentan destaparlo, tirando de la manta de su cama (como ocurre -y estamos acostumbrados a ver- en muchas películas de terror). Es en este momento cuando Miguel Ángel Hernández evoca un viaje que realiza junto con su mujer a Belchite Viejo, en Zaragoza ${ }^{17}$ :

17 Este mismo viaje, encuadrado, obviamente, desde otro punto de vista, se narra también en el ya citado diario: $c f r$. Hernández 2019a: 30-31. Las reflexiones sobre los desastres de la guerra son parecidas. 


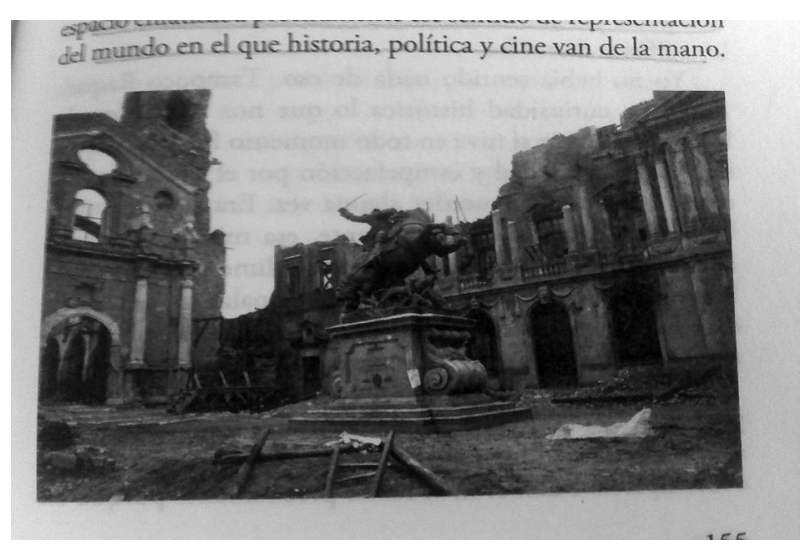

Fig. 5. La visita de Münchausen, 1987.

(c) Francesc Torres. Cortesía del artista.

... el pueblo que Franco había dejado en ruinas para hacer visible la barbarie del bando republicano. En mi libro sobre Walter Benjamin y el arte contemporáneo había dedicado unas páginas a estudiar los diferentes proyectos artísticos que el artista catalán Francesc Torres había realizado sobre ese territorio de escombros y llevaba tiempo queriendo visitarlo. Me resultaban excepcionales y sugerentes sobre todo las fotografías que había tomado a finales de los ochenta, poco tiempo después de que Terry Gilliam rodara allí Las aventuras del barón Münchausen. En ellas podían verse los restos del rodaje mezclados con los vestigios de la destrucción real. Dos ruinas entrelazadas. También dos escenarios. Porque mantener el pueblo derruido como representación de la barbarie no era otra cosa que convertirlo en un escenario (155).

De nuevo, las imágenes que se solapan de forma anacrónica provocan una reflexión que vierte tanto sobre la memoria como sobre nuestras relaciones con el pasado, en este caso, con la historia del pasado reciente de España. La imagen que, a esta altura del texto, interrumpe la narración, muestra efectivamente La visita de Münchausen (fig. 5), esto es, una de las fotos del artista citado por el autor en su ensayo Materializar el pasado. El artista como historiador (benjaminiano) ${ }^{18}$, publicado en el 2012, esto es, seis años antes de El dolor de los demás.

Lo que más llama la atención de esa foto de Torres, lo que Barthes definiría como el punctum de la imagen (Barthes 1990: 63-66 y 87-89), es la cabeza cortada del jinete que esgrime una espada en el aire, en el acto eternamente pospuesto (o desplazado) de cortar las cabezas de sus enemigos y de cantar (o celebrar) la victoria. La mirada no se fija sobre los escombros, las piedras, las columnas de la iglesia y de

${ }_{18}$ Cfr. Hernández 2012 (en particular, el cap. 3, Abrir el trauma: prácticas de historia en el arte español del siglo XXI, 75-110). 


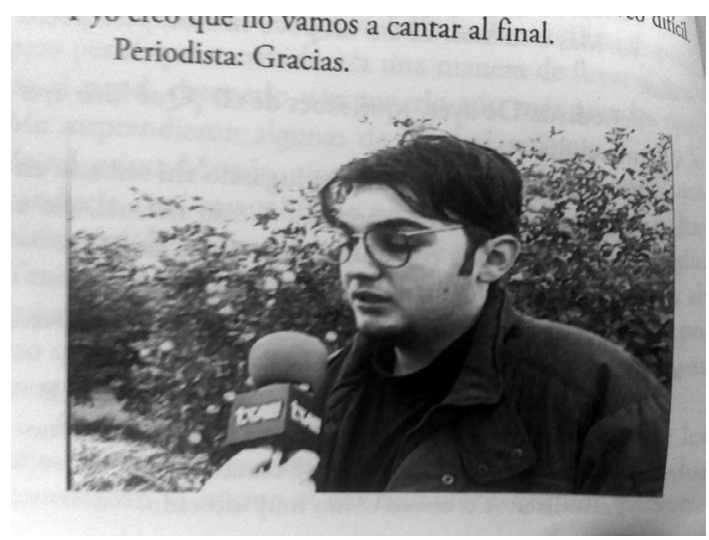

Fig. 6. Captura de pantalla del telediario matinal de TVE Murcia, 26/12/1995. Cortesía de RTVE Murcia.

los demás monumentos que aparecen en el encuadre, sino precisamente en algo que falta, en un vacío: la cabeza del soldado (presumiblemente franquista) montado en un caballo que está corriendo hacia el triunfo acompañado de dos perros. El espectador se verá obligado a preguntarse jes este monumento algo que Terry Gilliam ya se encontró en Belchite Viejo o, en cambio y al revés, se trata de algo que re-construyó para su película de 1988 (película -recordémoslo- basada en un personaje a mitad entre la realidad y la ficción y perteneciente al siglo XVIII)? A falta de respuestas ciertas, y más allá de la posibilidad de encontrar una respuesta unívoca a esta pregunta, lo que sí es evidente es que la imagen concentra en un mismo encuadre y de forma perturbadora la realidad histórica (y trágica) de la guerra civil española y la realidad ficticia (y cómica) de las aventuras que el director de The Man Who Killed Don Quixote (2018) trasladó a la gran pantalla en homenaje al famoso personaje histórico del barón de Münchausen (destinado a convertirse a lo largo de los siglos en personaje literario clásico de nuestro imaginario colectivo). Es interesante el testimonio de Francesc Torres: «El pueblo parecía un cadáver maquillado y vestido de payaso» (Torres 2007: 3) ${ }^{19}$. Y es que, efectivamente, Terry Gilliam rodó las escenas de su película cómica en los mismos sitios en los que los franquistas cavaron las fosas comunes donde siguen los cadáveres de los republicanos ${ }^{20}$.

En el mismo capítulo citado, el lector podrá contemplar la cara del autor (fig. 6) cuando ocurrieron los hechos. Tras muchos altibajos y dudas sobre si seguir

19 La costumbre (malsana) de maquillar a los cadáveres del enemigo como forma extrema de ultraje moral fue algo común también a lo largo de la guerra civil, como demuestra (con material visual objetivamente impactante) Preston 2011.

${ }^{20}$ Sobre este nudo, es fundamental Schlögel 2007 (hay un capítulo en el que el autor reconstruye la vida de Walter Benjamin a partir de las bibliotecas que frecuentó antes de darse a la fuga - de los nazis-y encontrar la muerte en Port Bou). 
escribiendo sobre este evento traumático de su pasado personal, Miguel Ángel Hernández consigue la cinta de vídeo del telediario local durante el cual un periodista lo entrevistó sobre el homicidio de su mejor amigo.

$Y$ esta es la descripción que el autor hace de su propia imagen, sacada de un fotograma de la entrevista (entonces, a diferencia de las demás citadas, esta no es propiamente una fotografía, sino un pantallazo, o captura de pantalla, a partir de un vídeo de los años noventa: la visibilidad del yo se verá afectada también por la visualidad distorsionada que ofrece un fragmento sacado de un vídeo: la materialidad de la imagen influye en su propia configuración y recepción por parte del que la contempla):

El rostro aniñado, los ojos enrojecidos, la perilla incipiente, la piel tersa, el flequillo sobre las gafas de metal, y mi cazadora verde que ahora sería vintage y moderna. Pero sobre todo mi modo de hablar. Mi acento murciano, mi inseguridad, mi timidez, mi tartamudeo. Apenas había salido de la huerta. Los limoneros que servían de fondo a la escena seguían siendo parte de mi hogar. Muchas cosas han cambiado. Pero otras muchas siguen en el mismo lugar (185).

En este caso lo siniestro surge precisamente de la contemplación de un yo del pasado en relación con el cual el yo del presente no se reconoce del todo y lo percibe como no-familiar: si el pasado siempre parece más inocente que el presente es porque en el pasado desconocíamos muchas de las cosas que luego modificarían ese mismo pasado y determinarían el futuro. Los elementos de su propio aspecto físico que el autor pone de relieve son los que más desentonan con la imagen del presente: si en la imagen en cuestión Miguel Ángel Hernández se ve como a un niño, o alguien aniñado, en el presente se ve como la versión envejecida de ese mismo cuerpo:

La perilla incipiente se ha convertido en barba. El flequillo sobre los ojos ha desaparecido, como casi todo el pelo de la cabeza. Las gafas grandes de metal las he sustituido por gafas grandes de pasta. Cuando ahora estoy delante de una cámara pronuncio las eses y no me avergüenza hablar en público -no tanto como entonces- (185).

Lo que cambia no es solo el aspecto físico, sino también la voz, piedra de toque del cambio radical (o metamorfosis interna) que ha sufrido ese yo del pasado: gracias a la universidad y a sus estudios de Historia del Arte, el Miguel Ángel adolescente que habla en la entrevista ha podido huir de la huerta murciana (encarnada metonímicamente por los limoneros que se ven en el segundo plano) en la que nació y vivió sus primeras experiencias vitales, y ha conseguido abrirse a la vida en la capital de la región, para luego empezar a viajar por el mundo. Lo único que queda de ese joven parece ser solo el peso («algo más de cien kilos») y la mirada («la misma mirada triste»). La periodista que le facilita ese vídeo al autor se sorprende durante el visionado y le dice que "pareces otra persona» (185). Las fotografías de nuestros rostros del pasado desencadenan la pregunta socrática: ¿me conozco de verdad a mí mismo?, declinable también según esta versión: ¿’he llegado nunca a conocerme? O como dice el narrador: «¿Soy otra persona? ¿Soy el mismo?» (186). El autor no encuentra una respuesta cierta a estas preguntas. Toda imagen de nuestro yo pasado 
es una refutación del imperativo socrático. Nadie se conoce a sí mismo, ni siquiera a través de la contemplación de sus imágenes del pasado ${ }^{21}$.

La última imagen que aparece explícitamente dentro del cuerpo del texto es la fotografía de una obra de arte contemporáneo y forma parte del último capítulo, el vi, titulado La zona de sombra (un título muy cercano a la poética de Javier Marías, cuya columna dominical en El Pais se titula precisamente así).

Se trata de Los ojos de Gutete Emerita del artista chileno Alfredo Jaar.

El fotógrafo se centra en el detalle de los ojos de la protagonista para mostrar precisamente «la mirada que ha visto de cerca la muerte, pero no la imagen de los cadáveres mutilados en el genocidio de Ruanda, los cuerpos sin nombre y sin

${ }^{21}$ Lo explica muy bien Philip Dubois en su ensayo L'act photographique (1983): cfr. Dubois 1986: 85: «Toda foto implica pues que haya, bien diferenciados uno del otro, el aquí del signo y el allí del referente» (las cursivas son del autor); lo mismo afirma George Didi-Huberman en una entrevista concedida a Gerardo de la Fuente en México: «... la imagen no es una cosa en sí, es algo relativo a alguna otra cosa. La imagen es una función ligada a una alteridad», en de la Fuente 2016. No hay alteridad más evidente (y ejemplo más claro de siniestro en acción) de la que el sujeto observa contemplándose a sí mismo en una foto que le restituye de golpe su yo de hace veinte años, como demuestra Hernández en este fragmento de su novela; y no solo por lo que concierne al plano de la vista y de la visualidad, sino también al del oído y de la escucha de una voz que parece la de otro (u otro-yo). Siempre seremos otros con respecto a nuestros yoes pasados. También lo sabía muy bien Michel de Montaigne, antes del invento de Daguerre: «Yo, ahora, y yo antes, somos dos individuos» (cfr. Montaigne 1912: libro III, cap. IX, De la vanidad). Quizás la sobredosis de selfis en la actualidad se deba a una deliberada decisión de olvidar (o borrar rápidamente) al yo (del) pasado y de eternizar a un hipotético yo (del) presente en posturas siempre sonrientes y favorecedoras. En las redes sociales nadie llora ni se muestra triste o deprimido; estaría mal visto y chocaría precisamente porque en ese ámbito se excluye a priori todo lo que pueda transmitir dolor o estar asociado al malestar íntimo o personal del que publica su propio autorretrato fotográfico. Sobre este nudo, que es al mismo tiempo síntoma y epítome de un decidido cambio o giro conceptual en cuanto a nuestra manera de relacionarnos con nuestra identidad y con la construcción de la misma a través de la fotografía, $c f r$., entre otros, Fontcuberta 2016. Kant reflexiona sobre el desdoblamiento de la percepción del yo en esta nota del $\$ 4$ ("Del observarse a sí mismo») de su Antropología en el sentido pragmático: cfr. Kant 2019: 44-45: «En la Psicología nos estudiamos a nosotros mismos en nuestras representaciones del sentido interno; en la Lógica, en lo que pone en nuestras manos la conciencia intelectual. Ahora bien, aquí nos aparece el yo ser doble (lo que sería contradictorio): 1) el yo en cuanto sujeto del pensar (en la Lógica), que significa la pura apercepción (el mero yo que reflexiona) y del cual no hay absolutamente nada más que decir, sino que es una representación perfectamente simple; 2) el yo en cuanto objeto de la percepción, o sea, del sentido interno, el cual encierra una multiplicidad de determinaciones que hacen posible una experiencia interna. La cuestión de si en los variados cambios internos del alma (de su memoria o de los principios admitidos por ella), el hombre, cuando es consciente de esos cambios, puede decir aún que es exactamente el mismo (en cuanto al alma), es una cuestión absurda; pues el hombre solo puede ser consciente de estos cambios representándose a sí propio como uno y mismo sujeto, y el yo del hombre es sin duda doble por su forma (por la manera de representárselo), pero no por su materia (por el contenido representado)» (las cursivas son del autor). Obviamente, lo que para Kant (en 1798) era una "cuestión absurda" para el Henri Bergson de Materia y memoria (de 1896) y para el Sigmund Freud de la Interpretación de los sueños (de 1899) será el prólogo, casi podríamos decir que el motivo desencadenante, para la elaboración y el desarrollo de sus respectivas teorías sobre el funcionamiento del mundo del inconsciente (en relación con la percepción del tiempo) y del lenguaje peculiar y asistemático de ese mismo mundo. 


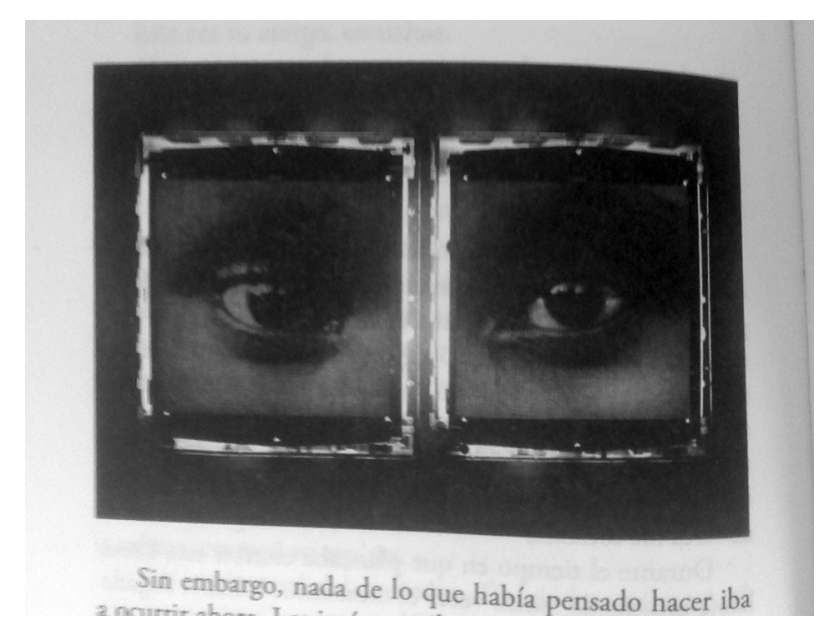

Fig. 7. Los ojos de Gutete Emerita, 1996.

(C) Alfredo Jaar. Cortesía del artista.

historia» (fig. 7) (279). El autor cita a Alfredo Jaar en la conclusión de la novela, cuando, decidido a contemplar las fotos que la policía sacó en el lugar del crimen y, luego, del suicidio del asesino, se topa con la negativa del secretario judicial que podría facilitárselas. Esta es la reacción de quien, investigando en el caso de Nicolás y Rosi, se da cuenta de que tampoco le serviría de nada contemplar esos dos cadáveres:

¿Qué iba a solucionar viéndolas? Solo habría servido para volver a victimizar a la víctima. Ver a Rosi en camisón, llena de sangre, sería volverla a matar. Contemplar el cuerpo de Nicolás destrozado después de la caída no me proporcionaría ninguna verdad. En la era de la transparencia, cuando todo debe ser visto, dicho y conocido, tal vez sea necesario que ciertas imágenes permanezcan para siempre al otro lado del espejo, más allá de la visión, en el envés de la mirada (280-281).

Citar, entonces, a Alfredo Jaar e introducir, en particular, la foto de la mujer víctima y testigo ocular de las masacres entre tribus rivales en el Ruanda de los años noventa no es un acto inocuo ni tampoco casual. En este caso, la pregunta que el lector (espectador) se hace no es ¿qué es una imagen? (pregunta de tipo ontológico, cercana a una postura filosófica kantiana), sino más bien ¿qué quiere comunicarnos esa imagen? ¿Qué hace ahí esa imagen? (pregunta de tipo heurístico, cercana a la postura que Walter Benjamin cultivó en sus análisis de la fotografía, pero también del cine y del arte a él contemporáneos).

Entonces, volvamos a contemplar esa imagen y a preguntarnos ¿qué es lo que vemos en Los ojos de Gutete Emerita? La respuesta requiere la participación activa del espectador: solo el que sabe que esta fotografía forma parte de un proyecto de 1996 sobre el genocidio ruandés podrá empezar a utilizar su propia imaginación para intentar captar qué se esconde detrás de ese primer plano, qué horrores han 
tenido que contemplar esos ojos, poniéndose, de hecho, en el lugar del otro ${ }^{22}$. Se trata de un primer plano que adquiere inmediatamente una alta carga ética, precisamente a la hora de no mostrar la violencia de los que mataron a centenares de víctimas inocentes y de mostrar, en cambio, y al revés, la mirada del otro. Y la clave está en el hecho de que, como nos recuerda Susan Sontag, «al otro, incluso cuando no es un enemigo, se le tiene por alguien que ha de ser visto, no alguien (como nosotros) que también ve» (Sontag 2019: 65). Alfredo Jaar nos muestra de forma explícita que ahí hay alguien que también ve y que, a lo mejor, estuvo forzado a ver (el horror que lo rodeaba).

Se trata de un discurso que contiene una alta carga ética: ¿̨hasta qué punto se puede llegar en la búsqueda del tiempo perdido si ese mismo tiempo perdido involucra a personas que han muerto de forma violenta y que ya no están ni pueden defenderse u ofrecer otra versión de los hechos? ¿Hasta qué punto puede explotar su afán investigador alguien que siente la necesidad de ver a las víctimas?

Miguel Ángel Hernández es muy claro en la respuesta que nos ofrece en el fragmento citado: contemplar a Rosi en el charco de sangre producido por los golpes del radiocasete con que Nicolás la mata sería «volverla a matar». Tiene razón el autor y narrador cuando afirma que hay imágenes que es mejor que se queden «al otro lado del espejo» $y$ «en el envés de la mirada ${ }^{23}$. Son imágenes que no sirven para explicar lo que pasó, imágenes que entran dentro de la categoría que Susan Sontag definiría como "las fotografías de atrocidades», esas fotos que "pueden producir reacciones opuestas. Una llamada a la paz. Un grito de venganza o simplemente la confundida conciencia [...] de que suceden cosas terribles» (Sontag 2019: 18).

Tampoco es casualidad que justo en ese momento, esto es, en el momento en el que al autor-investigador se le impide la visión de las fotos de los cadáveres, el mismo empieza a entender y a esclarecer ante sí mismo el porqué del acto de escritura: «A veces se escribe para conocer. Otras, para saber cuándo parar. Y también en ocasiones se escribe para aceptar que hay cosas que no siempre podemos saber»

${ }^{22}$ Cfr. Jaar 2011. Además de promover la empatía con el sujeto fotografiado, está claro que este tipo de encuadre nos obliga (o nos invita) a mirar nuestra propia mirada, como si la fotografía del primer plano de los ojos de la mujer se convirtiera en un espejo en el que contemplarnos a nosotros mismos: sobre este nudo sigue siendo esclarecedor el artículo «El estado del espejo como formador de la función del yo [je] tal como se nos releva en la experiencia psicoanalítica» de Jacques Lacan: $c f r$. Lacan 1978: 90: «... el estadio del espejo es un drama cuyo empuje interno se precipita de la insuficiencia a la anticipación, y que para el sujeto, presa de la ilusión de la identificación espacial, maquina las fantasías que se sucederán desde una imagen fragmentada del cuerpo hasta una forma que llamaremos ortopédica de su totalidad». No sabemos si Alfredo Jaar ha leído a Lacan; sí es cierto que, en relación con el concepto de «imagen fragmentada» y de "forma ortopédica», ese mismo primer plano de los ojos de Gutete Emerita se repite desmembrado en múltiples copias a lo largo de toda la instalación, como puede verse en Jaar 2019.

${ }^{23}$ Sintagma que recuerda el título de otra recopilación de cuentos del autor: $c f r$. Hernández 2004 (el título aparece citado en la p. 247 de El dolor de los demás). 


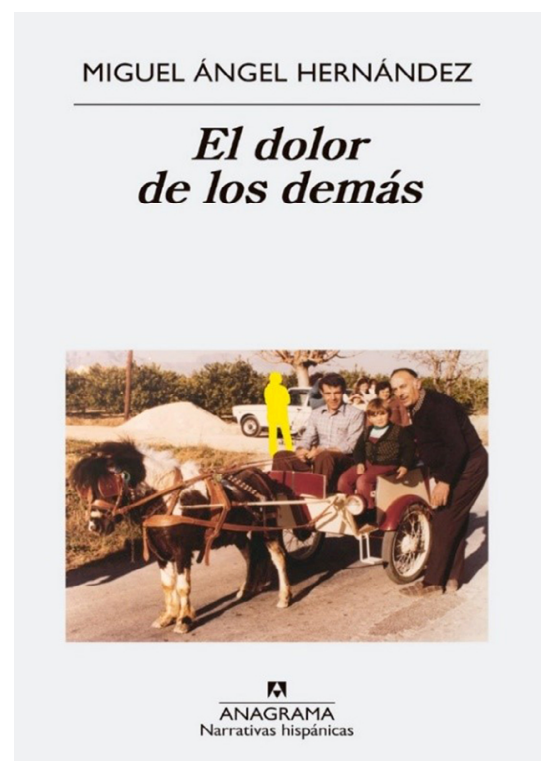

Fig. 8. Portada de El dolor de los demás, 2018. (C) Anagrama.

$(285)^{24}$. Y esto es parte del proceso de descubrimiento y crecimiento consciente de su propio yo que nos permite hablar de la forma del Bildungsroman en relación con El dolor de los demás. Escribiendo del «dolor de los demás», el autor se da cuenta de que no puede desentrañar el misterio y de que el fracaso de su hazaña literaria se convierte, paradójicamente, en el éxito de su acto de búsqueda del tiempo perdido. Etapa fundamental de ese proceso será, de nuevo, y precisamente en el cap. v, el que da el título a la novela, El dolor de los demás, el descubrimiento repentino e inesperado de una fotografía, la única, de las hasta aquí analizadas, que no aparece explícitamente dentro del cuerpo del texto, sino que dialoga con el paratexto, obligando al lector a establecer un doble nivel de lectura entre texto y paratexto.

Me refiero a la foto de la portada (fig. 8), en la que se ve al autor nińo, acompańado por su padre y por un vecino y montado en un carruaje tirado por un poni. Con la idea de ayudar a su amiga Concha Martínez Barreto, ocupada en crear un archivo de niños en carruaje, Miguel Ángel Hernández da con una foto perfecta para tal objetivo y sacada de los típicos álbumes familiares:

${ }^{24} \mathrm{El}$ autor llegará a la misma conclusión en el diario: al relatar el encuentro del todo azaroso con la mujer del juez que levantó el cadáver de Nicolás y de Rosi, el autor opta por dejar de investigar y por borrar de su móvil el número que le entrega la mujer del mismo juez; Javier Cercas, testigo del encuentro presenciado por Hernández, sentenciará: «-Se ha cerrado el círculo [...]. La novela está terminada. Tómate una cerveza y relájate» (Hernández 2019a: 265). 
Yo debía de tener unos cuatro o cinco años. Vestía un mono rojo de pana y una chaqueta verde. Estaba sentado en un pequeño carro tirado por un poni parduzco. A mi lado, el conductor, el Churrispas - un vecino de la huerta-tenía en sus manos las riendas del poni. Junto al carro, de pie, con un jersey azul y unas alpargatas de cuadros, mi padre pasaba el brazo por detrás de mi espalda. Los tres posábamos para el fotógrafo, seguramente mi tío Emilio, que siempre llevaba la cámara en la mano (244).

La écfrasis de la fotografía toma relieve y empieza a ocupar el primer plano en el curso de la lectura sobre todo en el momento el que el lector entiende que el autor se está refiriendo a la imagen de la portada del libro que lleva entre sus manos. Lo que está dentro del texto, de repente, empieza a trasladarse hacia lo que está fuera (en los «umbrales del texto», según la famosa definición genettiana), esto es, en lo primero que vemos cuando nos topamos con un libro: la imagen de la portada. ¿Y qué es lo que nos llama la atención de esa imagen? Precisamente el hecho de que, de entre todas las figuras humanas que se atisban o se entrevén en el segundo plano, hay una, y solo una, que está borrada del conjunto, que aparece siendo ausente o que aparece como una ausencia muy elocuente: la figura amarilla, de pie, encuadrada de perfil y que parece mirar fuera del encuadre, porque parece no atender lo que están haciendo los demás (posar para una foto familiar). Esta es la descripción que nos ofrece de la misma el autor a esta altura de la trama de la novela:

Una chica, alta, vestida de negro, con el pelo recogido y la mirada perdida. Fuera del grupo, separada de todos.

En todos los años en que esa foto había estado en mi memoria la figura nunca había aparecido ahí. Había logrado identificar el rostro borroso de mi madre, incluso el de mis primas, y en cambio jamás había mirado la imagen con la suficiente atención como para detectar su presencia. Esa tarde, sin embargo, mis ojos se fueron rápidamente hacia el fondo de la fotografía, como si esa figura reclamase mi mirada. Había estado ahí desde un principio, pero solo ahora podía -quería o sabía- verla: Rosi, en el centro de la imagen, con los brazos cruzados, afirmando su presencia en la fotografía (245).

De fantasma del pasado, tras veinte años de los eventos rememorados, la víctima vuelve a ser alguien que capta la mirada del observador, alguien cuya presencia se hace literalmente visible ${ }^{25}$. Y es precisamente la toma de conciencia de que,

25 Sobre este nudo, $c f r$. Borsò 2012: 35-36: «Proprio la qualità evenemenziale dell'estetica interstiziale porta a considerare un momento cruciale finora non valutato, e cioè lo statuto del soggetto che si espone al suo inter-esse, al suo intreccio con il mondo, per esprimersi con le categorie della fenomenologia di Merleau-Ponty. Qui il soggetto -come nel teatro sperimentale o come ha proposto Roland Barthes per il punctum della fotografia- non è più sovrano di ciò che vede o ascolta, ma si sente parte del mondo o addirittura investito dalla sua presenza». Sobre esta foto $c f r$. también el diario: «La foto abre todos los recuerdos. Y el pasado que regresa se queda contigo» (Hernández 2019a: 122). Sobre el motivo por el cual esta foto se convierte en la imagen de la portada $c f r$. Hernández 2019a: 248-249: el autor, al percatarse de la presencia fantasmal de Rosi, esto es, de la víctima, 
hasta ese momento, la había puesto de lado, como elemento secundario de la historia, siendo el protagonista principal su mejor amigo, el elemento determinante que empujará al autor a modificar la estructura de su propia novela y a dejar espacio y dar voz a la víctima; como notado acertadamente por parte de Pozuelo Yvancos, es a partir de este momento cuando la novela da un giro radical y la búsqueda del tiempo perdido empieza a cobrar su pleno sentido:

Su imagen me habló desde el pasado, me empujó a buscarlo, a interrogarme por aquello que no había dicho ni escuchado. Sentí la punzada de la imagen en el cuerpo. Y no pude escapar a lo que requería de mí. Abrirme a su memoria. Tratar de conocerla. Para que nunca más fuera solo una sombra. Para poder volver a mirar la fotografía y saber que detrás de aquella figura había una vida. Una existencia arrancada de cuajo. Una historia que ya no podía postergar (246).

Es la «punzada», traducción casi literal del punctum barthesiano, el elemento emocional y visual, material y físico, que determinará el cambio de ritmo y la estructura interna de la narración, cuando, finalmente, el autor preguntará a su prima Loles informaciones y anécdotas relacionadas con Rosi, que fue su mejor amiga exactamente como Nicolás lo fue para él durante la infancia y la adolescencia.

La escritura adquiere una carga ética notable, casi palpable, porque frente a la imposibilidad de averiguar la verdad (¿por qué Nicolás mató a su hermana?) el autor descubre la posibilidad de ceder la palabra a otra testigo ocular, a una viva que estuvo en contacto directo e íntimo con la víctima hasta el último día de su vida.

El punctum, entonces, es el detonante de otra escritura, de otro tipo de narración, pautada por un lenguaje coloquial, a través del cual Miguel Ángel Hernández deja hablar al otro que, como nos recuerda Sontag, no solo está allí para que nosotros lo miremos, sino también para mirar y, como en este caso, para hablar, para dar su versión de los hechos.

Es como si, al contemplar la fotografía familiar, el autor se percatara de la realidad que se esconde detrás de la apariencia: de forma parecida a lo experimentado por el protagonista de Las babas del diablo de Julio Cortázar, también Miguel Ángel Hernández se da cuenta de que, como afirma Benjamin (2018: 69), «penetramos el misterio solo en el grado en que lo reencontramos en lo cotidiano por virtud de una óptica con capacidad dialéctica para percibir lo cotidiano como impenetrable y lo impenetrable como cotidiano».

se da cuenta de que «No sólo las palabras narran. También las imágenes. Las que se van y las que se ocultan» (249). Esta frase es un eco de otra que se remonta al principio del acto de escritura del diario: «Las fotos y la memoria son capaces de traer los recuerdos al presente. Pero son las palabras las que dan verdadero sentido a lo vivido» (Hernández 2019a: 33). A estas alturas podemos afirmar que ambos (tanto el diario como la novela) se desarrollan precisamente gracias al impacto bidireccional de las imágenes sobre las palabras y de estas sobre aquellas. 
Y es que las imágenes, tanto las fotográficas como las que surgen del arte, del cine o de cualquier otra fuente tecnológica, encierran siempre un misterio, para el que esté preparado para interrogarlas.

\section{CONCLUSIONES}

El dolor de los demás se configura como una novela en la que las imágenes no representan solo simples elementos decorativos o subsidiarios, ni tampoco se presentan como algo subordinado al texto escrito. Si volvemos a leer Intento de escapada y, seguidamente, El instante de peligro, nos daremos cuenta de que también en estos dos casos el autor juega con las imágenes (reales o inventadas) para estimular la imaginación del lector e involucrarlo de forma activa en la re-construcción de los hechos narrados. Si en Intento de escapada el narrador se interroga sobre la validez ética de las propuestas estéticas del arte contemporáneo más extremista, en $E l$ instante de peligro el joven profesor de Historia del Arte en búsqueda del sentido último de un fotograma de una película misteriosa y aparentemente inubicable en el espacio geográfico de la realidad empírica llevará a cabo una reflexión compleja sobre las relaciones entre imagen y palabra ${ }^{26}$.

En El dolor de los demás las cosas se complican ulteriormente: esta vez quien narra no es ni un personaje de ficción ni un narrador pseudoautobiográfico; aquí habla el autor, que cita explícitamente a sus familiares, a los amigos de su vida en la huerta murciana, que nos enseña sus fotos de cuando era un joven adolescente todavía ignaro del trauma que le causaría el asesinato de Rosi por manos de su hermano. Las dos primeras imágenes son recortes de periódico. Se trata de imágenes aparentemente neutras. Pero basta con mirarlas con atención para descubrir, en la primera, una especie de re-escritura (o de referencia intertextual implícita) de algunos cuadros de Caspar David Friedrich, y en la segunda, una especie de salto atrás en el tiempo, una foto sacada de El Caso, una revista morbosa que, según el autor, encarnaría en parte el espíritu cainita de la España franquista (y, a lo mejor, de Espańa a secas: como si cada nuevo asesinato cruel pondría al día el eterno espíritu fratricida de los españoles).

La tercera imagen, La visita de Münchausen, de Francesc Torres, es parte de una obra de arte contemporáneo y se convierte en un elemento visual central para reflexionar sobre la heterocronía que se desarrolla en el momento en el que el fotógrafo solapa las ruinas reales de Belchite Viejo (uno de los teatros de los conflictos violentos de la guerra civil española) con las ruinas ficticias y creadas ad hoc por Terry Gilliam en el momento en el que utiliza ese pueblo real como escenario para su película sobre el famoso barón alemán.

${ }^{26}$ El título de esta novela viene del Benjamin de las «Tesis sobre filosofía de la historia»: $c f r$. Benjamin 1973: 175-194. Cada capítulo de la novela empieza con un exergo de este ensayo. 
La cuarta imagen es una captura de pantalla del vídeo de la entrevista que la televisión local le hizo a Miguel Ângel Hernández el día siguiente al asesinato y al suicidio de Nicolás. No se trata propiamente de una fotografía; pero el autor la utiliza como si lo fuera, para llevar a cabo una reflexión sobre la imposibilidad del yo del presente de tomar conciencia plena de su yo del pasado.

La quinta imagen, de nuevo, es una pieza de un puzle más grande: Los ojos de Gutete Emerita, de Alfredo Jaar, nos muestra la mirada de una mujer que tuvo que sufrir los estragos de la guerra civil en su país natal. Se trata de una imagen fundamental para entender el compromiso ético tanto del artista chileno como del escritor murciano: en lugar de contemplar a los cadáveres de las víctimas, a veces, merece la pena parar y dejar "fuera de campo», en el «envés de la mirada», lo particularmente violento o cruel. La escritura sirve también para fracasar en el intento de contar el horror.

La sexta y última imagen no aparece en el cuerpo del texto, sino que brilla en todo su esplendor en la portada, esto es, en los umbrales del texto. Se trata a lo mejor de la imagen más importante, porque es a partir del descubrimiento de la presencia de Rosi (la víctima) en esa fotografía cuando Miguel Ángel Hernández cambiará el ritmo y la estructura interna de su novela para ceder la palabra (a través de otra testigo ocular: su prima Loles) a la que fue silenciada con la violencia (en el pasado) y a la que podrá volver a hablar (en el presente) a través del acto de escritura en el que el autor reproducirá la entrevista llevada a cabo con Loles.

Reflexionando sobre algunas fotografías de Atget, Walter Benjamin se pregunta:

¿Pero no es cada rincón de nuestras ciudades un lugar del crimen? ¿No es cada transeúnte un criminal? ¿No debe el fotógrafo - descendiente del augur y del arúspicedescubrir la culpa en sus imágenes y señalar al culpable? (Benjamin 2018: 90) ${ }^{27}$.

Miguel Ángel Hernández nos demuestra con El dolor de los demás que hay culpables cuyos delitos quedan inexplicables y hay víctimas cuyas vidas pueden volver a iluminar el presente a pesar de las injusticias del pasado y del presente. Además de que toda imagen puede encarnar lo que Freud definió como siniestro. Lo que de verdad importa es saber leerlo e interpretarlo. Y, si uno es capaz, también contarlo.

Recibido: julio de 2020: ACEPTADo: abril de 2021

27 Sobre la fotografía como fuente primordial para una reflexión que puede narrativizar el mundo a partir del poder hermenéutico de la mirada (con consecuente y enriquecedora mezcla entre género ensayístico y género narrativo), $c f r$. estos dos recientes ejemplos magistrales: Dyer 2016 y Cousins 2018; ambos consiguen abrirnos los ojos tanto sobre el significado escondido de algunas fotografías emblemáticas de la historia de este arte como sobre los nudos que atañen todavía nuestra contemporaneidad (a partir de la reconstrucción de la identidad fragmentada precisamente por la multiplicidad y heterogeneidad de los espacios y los tiempos en la que esta se refleja, entre espejos rotos y espejismos engañosos). 


\section{BIBLIOGRAFÍA}

Agamben, Giorgio (1998): Quel che resta di Auschwitz, Milano: Bollati Boringhieri.

Agamben, Giorgio (2002): Lo que queda de Auschwitz, Valencia: Pre-Textos.

Alberca, Manuel (2017): La máscara o la vida. De la autoficción a la antificción, Málaga: Pálido Fuego.

Alberca, Manuel (2020a): «¿Vivir o escribir? Los diarios de Miguel Ángel Hernández», Clarín. Revista de nueva literatura xxv, 145: 17-20.

Alberca, Manuel (2020b): «Miguel Ángel Hernández: el tríptico del arte o la vida», Cuadernos Hispanoamericanos 838 . URL: https://cuadernoshispanoamericanos.com/miguel-angel-hernandez-el-triptico-del-arte-o-la-vida/; 15/07/2020.

Angelucci, Daniela (2017): "Tra la mano e il metallo. Freud, Benjamin e l'inconscio ottico», L'inconscio. Rivista di Filosofia e Psicanalisi 3: 47-57.

Barthes, Roland (1990): La cámara lúcida. Notas sobre fotografía, Barcelona: Paidós.

Benet, Juan (1983): «Ilusitana», en Juan Benet, Artículos, volumen I (1962-1977), Madrid: Ediciones Libertarias, 35-50.

Benjamin, Walter (1973): Iluminaciones I, Madrid, Taurus.

Benjamin, Walter (2018): Iluminaciones, Madrid: Taurus.

Borsò, Vittoria (2012): «Sulla soglia tra visibilità e dicibilità. L'evento della visualità nel materiale dell'immagine», en Maurizio Ponzi y Dario Gentili (eds.), Soglie. Per una nuova teoria dello spazio, Milano-Udine: Mimesis, 31-46.

Candeloro, Antonio (2008): «Visiones transversales: los documentos visuales en algunas novelas contemporáneas», en Fundación Luis Goytisolo (ed.), Aspectos de Literatura Comparada. Homenaje a Claudio Guillén. Actas del XV Simposio Internacional sobre Narrativa Hispánica Contemporánea, El Puerto de Santa María: Fundación Luis Goytisolo, 53-67.

CANDeloro, Antonio (2018): «Saber mirar (entre la ética y la estética): Intento de escapada (2013) de Miguel Ángel Hernández», Tonos Digital 35, 1-30.

Candeloro, Antonio (2019): «Fronteras de lo visible y de lo literario», en Víctor Sanchis Amat, Laura Palomo Alepuz y Ana Andúgar Soto (eds.), Aproximaciones interdisciplinares a los estudios literarios, Alicante: Biblioteca Virtual Miguel de Cervantes, 127-140.

Cercas, Javier (2016): El punto ciego, Barcelona: Random House Mondadori.

Cousins, Mark (2018): Historia y arte de la mirada, Barcelona: Pasado \& Presente.

De la Fuente, Gerardo (2018): Pensadores contemporáneos en sintesis. URL: https://youtu.be/m4hLqgrxXdg; 15/07/2020.

Didi-Huberman, George (2004): Imágenes pese a todo: memoria visual del Holocausto, Barcelona: Paidós.

Dubois, Philip (1986): El acto fotográfico, Barcelona: Paidós.

Dyer, Geoff, (2016): El momento interminable de la fotografía, México: Ediciones VE.

Fontcuberta, Joan (2016): La furia de las imágenes, Barcelona: Galaxia Gutenberg;

Freud, Sigmund (1976): «Lo ominoso», Sigmund Freud, Obras completas, XviI, Buenos Aires: Amorrortu, 215-251.

Garroni, Emilio (1986): Senso e paradosso. L'estetica, filosofia non speciale, Roma-Bari: Laterza. 
Hernández, Miguel Ángel (2004): Infraleve. Lo que queda en el espejo cuando dejas de mirarte, Murcia: Editora Regional.

Hernández, Miguel Ángel (2011): Cuaderno [...] duelo, Murcia: Nausícaä.

HernÁndez, Miguel Ángel (2012): Materializar el pasado. El artista como historiador (benjaminiano), Murcia: Micromegas;

Hernández, Miguel Ángel (2018): El dolor de los demás, Barcelona, Anagrama.

Hernández, Miguel Ángel (2019a): Aqui y ahora, Madrid, Fórcola.

Hernández, Miguel Ángel (2019b): «La novela como laboratorio: espacios de contacto entre arte y literatura", Cuadernos Hispanoamericanos 823, 38-48.

JAAR, Alfredo (2019): Eyes of Gutete Emerita. URL: http://sammlung-zimmermann.com/collection/ alfredo-jaar-the-eyes-of-gutete-emerita-2/; 15/07/2020.

JAAR, Alfredo (2011): Ruanda's Proyect. URL: https://publicdelivery.org/alfredo-jaar-rwanda/; 15/07/2020.

Kant, Immanuel (1876): Crítica del juicio, seguida de las observaciones sobre el asentimiento de lo bello y lo sublime, trad. del francés por Alejo García Moreno y Juan Ruvira, Madrid: Iravedra. URL: http://manuelosses.cl/VU/Kant\%20immanuel\%20_\%20Critica\%20del\%20juicio. pdf; $15 / 07 / 2020$.

Kant, Immanuel (2019): Antropología, Madrid: Alianza.

Kermode, Frank (1983): El sentido de un final, Barcelona: Gedisa.

Lacan, Jacques (1978): Escritos I, México: Siglo XXI.

López López, Carmen María (2019): El cine en el pensamiento y en la creación de Javier Marias, Vigo: Academia Editorial del Hispanismo.

Marías, Javier (1998): Negra espalda del tiempo, Madrid: Alfaguara.

Montaigne, Michel (1912): Ensayos de Montaigne, París: Casa Editorial Garnier Hermanos. URL: http://www.cervantesvirtual.com/obra/ensayos-de-montaigne--0/; 15/07/2020.

Mora, Vicente Luis (2012): El lectoespectador, Barcelona: Seix Barral.

Mora, Vicente Luis (2019): «Entre estética y literatura: metodologías para leer el continuo textovisual de las obras literarias en la era digital», Actio Nova 3, 453-480.

Piazza, Marco (2014): «L'oggettività della fotografia e la conoscenza stereoscopica: da Proust a Barthes e ritorno", Lebenswelt 5, 92-105.

Pittarello, Elide (2014a): «Che ci fanno le fotografie nei romanzi?», en Augusto Guarino (ed.), Le geometrie dell'essere. Identità, identificazione, diversità nella recente letteratura spagnola, Napoli: Tullio Pironti, 249-275.

Pittarello, Elide (2014b): «Visión de Nueva York de Carmen Martín Gaite: el ojo, la mano, la voz», en José Teruel, Carmen Valcárcel (eds.), Un lugar llamado Carmen Martín Gaite, Madrid: Siruela, 154-174.

Pittarello, Elide (2020): Poesía e imagen, Murcia: Editum.

Pozuelo Yvancos, José María (2019): «El punto ciego de El dolor de los demás de Miguel Ángel Hernández», Ínsula 869, 36-38.

Preston, Paul (2011): El holocausto español. Odio y exterminio en la guerra civil y después, Barcelona: Debate. 
Quiñonero, Juan Pedro (2020): El cine comienza con Goya, Madrid: Cátedra.

Ricoeur, Paul (2006): El mal, Madrid: Amorrortu.

SÁnchez Zapatero, Javier (2019): «Una novela de vida: El dolor de los demás, de Miguel Ángel Hernández», Rassegna Iberistica 42 (111), 189-196.

SCHLÖGel, Karl (2007): En el espacio leemos el tiempo: sobre Historia de la civilización y Geopolitica, Madrid: Siruela.

Sontag, Susan (2018): Sobre la fotografía, Barcelona: DeBolsillo.

Sontag, Susan (2019): Ante el dolor de los demás, Barcelona: DeBolsillo.

Symons, A.J.A. (2005): En busca del Barón Corvo, Barcelona: Libros del Asteroide.

Torres, Francesc (2007): La visita de Münchausen, Barcelona: Raíña Lupa Galería Ediciones. 
